\title{
HUBUNGAN DUKUNAGN EMOSIONAL KELUARGA TERHADAP KUNJUNGAN LANSIA KE POSYANDU LANSIA DI GUNUNG SEMPU KELURAHAN TAMAN TIRTO KASIHAN BANTUL YOGYAKARTA.
}

\author{
Pratiwi Gasril \\ Staf dosen DIII Keperawatan Universitas Muhammadiyah Riau \\ e-mail :pratiwi@umri.ac.id
}

\begin{abstract}
Emotional support of the family is a safe and peaceful place to rest and also calm the mind. Tu juan this study to determine the relationship of emotional support for their families to visit the elderly to posyandu l Ansia Mount Sempu Village Tamantirto Poor Bantul, Yogyakarta. This research is non experimental research that is correlation research by using cross sectional approach. The instrument used in this study is a questionnaire for support emotional family and elderly visits seen from elderly visit from posyandu elderly. Sampling technique method used probality or random sample with 33 respondents and 10 respondents family. Dengunakan data analysis univariate, bivariate and analasisi and statistical tests digunak $a n$ is the Chi-square test. Result of research of relation of emotional support of family to visit lansi at posyandu elderly, got result of existence of meaningful relation from support arga emotionally numb with $(p$ value $=0.02)$. From the results of this study can be concluded that the elderly who visited the posyandu elderly need family support, especially emotional support, which can increase the spirit and motivation of elderly to visit posyandu elderly.
\end{abstract}

Keywords : Emotional support family, visit, posyandu elderly.

\section{PENDAHULUAN}

Pertumbuhan penduduk di seluruh dunia semaki cepat, khususnya orang lanjut usia (lansia) diperkirakan akan mencapai 1,2 miliar pada tahun 2025. Penduduk lanjut usia di indonesia akan meningkat $11 \%$ pada tahun 2020 dengan pencapaian angka harapan hidup 70-75 tahun (Nugroho, W. 2000).

Program pemerintahan dalam menangani masalah- masalah lanisa salah sarunya adalah mengadakan posyandu lansia , seperti yang dilakukan kabupaten sleman yang mengadakan program untuk mesosialisasikan tentang keberadaan posyandu lansia. Sosialisasi tersebut dapat menjadi sarana untuk memberikan informasi yang benar kepada masyarakat mengenai keberadaan dan dan fungsi posyandu lansia. Sebagian besar masyarakat beranggapan keberadaan posyandu lansia merupakan sarana pengobatan.
Posyandu lansia sangat berperan untuk mengetahui perkembangan kesehatan yang dialami seorang lansia (Sunartono. 2008).

Tujuan posyandu lansia anatara lain meningkatkan kemudahan lansia dalam mendapatkamn pelayanan kesehatan dasar dan rujukan, meningkat cakupan dan kualitas pelayanan kesehatan lansia, khususnya aspek peningkatan dan pencegahan tampa mengabaikan aspek pengobatan dan pemulihan serta meningkatnya kulitas pelaksanaan pelayanan kesehatan lansia. Sasaran langsung dari kegiatan ini adalah bagi para pra lansia ( usia 45-59 tahun), lansia (usia 60-69 tahun), lansia resiko tinggi yakni usia lebih dari 70 tahun atau lanjut usia berumur 60 tahun atau lebih.

Lansia membutuhkan rasa aman dan cintakasih dari lingkungan tempat lansia itu tinggal ${ }^{1}$. Pada umumnya para lanjut usia 
menikmati hari tuanya bersama dengan keluarganya, hal ini sesuai dengan nilai sosial budaya timur yang menyatakan bahwa orang tua yang berusia lanjut itu berhak dan pantas menerima perhatian dengan penuh penghormatan dan kemuliaan di tengah-tengah keluarganya (Dharmadi, A. 2005).

Fenomena yang terjadi saat ini peran serta keluarga yang mendukung lansia ke posyandu belum terlaksana dengan baik, seperti yang terjadi di Gunung Sempu Kelurahan Tamantirto Kasihan Bantul Yogyakarta yang menggambarkan kurangnya kemampuan keluarga melakukan dukungan secara langsung pada lansia. Hasil survei menunjukan rata-rata kunjungan lansia ke posyandu di Gunung Sempu Kelurahan Tamantirto Kasihan Bantul Yogyakarta dari bulan Februari 2008 - November 200850 orang atau 12,1\%. Hal ini jauh dari standar pelayanan minimal kunjungan ke posyandu lansia (Puskesmas Kasihan I, 2008)..

Berdasarkan uraian pada latar belakang masalah bahwa keluarga mempunyai peranan dan tanggung jawab yang penting dalam perawatan anggota kelurganya terutama lansia, maka peneliti mengajukan rumusan masalah : "Apakah terdapat hubungan dukungan emosional keluarga terhadap kunjungan lansia ke posyandu lansia di Gunung Sempu Kelurahan Tamantirto Kasihan Bantul Yogyakarta?" tujuan dari penelitian ini adalah untuk mengetahui hubungan dukungan keluarga terhadap kunjungan lansia ke posyandu lansia di Gunung Sempu Kelurahan Tamantirto Kasihan Bantul Yogyakarta. Kontribusi penelitian ini terhadap profesi keperawatan, terutama keperawatan keluarga. Dan Pengembangan teori Neuman untuk membantu dalam mencapai serta mempertahankan tingkat kesehatan secara optimal, khususnya lansia.

\section{METODOLOGI PENELITIAN}

Penelitian ini adalah penelitian non eksperimen. Data diperoleh dari kuisioner dan kunjungan lansia ke posyandu lansia dengan pendekatan cross-sectional untuk mengetahui adanya hubungan dukungan emosional keluarga terhadap kunjungan lansia di Gunung Sempu Kelurahan Tamantirto Kasihan Bantul Yogyakarta.

\section{HASIL PENELITIAN}

Penelitian ini dilakukan Sekolah Menengah Pertama (SMP) Bukit Raya Pekanbaru dengan hasil penelitian sebagai berikut:

\section{Tabel 1 Distribusi Frekuensi Dukungan Emosional Keluarga}

\begin{tabular}{cccc}
\hline No & Dukungan & (f) & $(\%)$ \\
\hline 1 & Rendah & 0 & $0 \%$ \\
\hline 2 & Sedang & 2 & $6,1 \%$ \\
\hline 3 & Tinggi & 31 & $93,9 \%$ \\
\hline & Total & 33 & 100 \\
\hline
\end{tabular}

Hasil analisis didapatkan mayoritas responden memiliki dukungan emosional yang tinggi dengan frekuensi sebanyak 31 orang dengan persentase sebanyak $93,9 \%$.

\section{Tabel 2 Distribusi Frekuensi Kunjungan} Lansia ke Posyandu Lansia

\begin{tabular}{lll}
\hline Kunjungan & (f) & $(\%)$ \\
\hline Tinggi & 23 & $69,7 \%$ \\
\hline Rendah & 10 & $30,3 \%$ \\
\hline Total & 33 & $100 \%$ \\
\hline
\end{tabular}

Hasil analisis menunjukkan bahwa dari 33 orang responden yang berkunjung ke posyandu lansia mayoritas rendah dengan frekuensi 10 orang dengan persentase $30,3 \%$.

Tabel 3 Hubungan Dukungan Emosional terhadap kunjungan lansia ke posyandu lansia

\begin{tabular}{ccccc}
\hline \multirow{2}{*}{ Dukungan } & \multicolumn{2}{c}{ Kategori } & & \\
& \multicolumn{2}{c}{ Kunjungan } & Total & $P$ \\
\cline { 2 - 3 } Rendah & Tinggi & & \\
\hline \multirow{2}{*}{ Sedang } & $0(0 \%)$ & $\begin{array}{c}2 \\
(100 \%)\end{array}$ & $\begin{array}{c}1 \\
(100 \%)\end{array}$ & 0,02 \\
\hline Tinggi & 10 & 21 & 31 & \\
\hline
\end{tabular}




\begin{tabular}{cccc}
\hline & $(32,3 \%)$ & $(67,7 \%)$ & $(100 \%)$ \\
\hline \multirow{2}{*}{ Total } & 10 & 23 & 33 \\
& $(30,3 \%)$ & $(69,7 \%)$ & $(100 \%)$ \\
\hline
\end{tabular}

Hasil analisis hubungan antar dukungan emosional terhadap kunjungan lansia ke posyandu lansia di peroleh bahwa terdapat dukungan emosional dengan kategori sedang sebanyak 2 dari 2 orang (100\%) dengan kategori kunjungan tinggi. Sedangkan sebanyak 21 dari 31 orang $(67,7 \%)$ dengan dukungan emosional dan kategori kunjungan juga tinggi. Hasil uji statistik di peroleh nilai $\mathrm{P}=0.024$ maka dapat disimpulkan ada hubungan antara dukungan emosional keluarga terhadap kunjungan lansia ke posyandu lansia.

\section{HASIL DAN PEMBAHASAN}

Hasil penelitian tentang hubungan dukungan emosional keluarga terhadap kunjungan lansia ke posyandu lansia, didapatkan hasil bahwa terdapat hubngan yang bermakna antara dukungan emosional keluarga terhadap kunjungan lansia ke posyandu lansia ( $p$ value $=0,02)$. Hal ini berarti dukungan emosional yang diberikan oleh keluarga dapat mempengaruhi kunjungan lansia ke posyandu lansia.

Dukungan emosional merupakan fungsi keluarga yang harus diterapkan kepada seluruh anggota keluarga termasuk kepada lansia ${ }^{8}$. Fungsi tersebut merupakan fungsi internal keluarga dalam memenuhi kebutuhan psikososial amggota keluarga, dengan cara saling mengasuh, cinta kasih, kenhangatan, dan saling mendukung dan menghargai antar anggota keluarga. Sehingga diharapkan dapat mempengaruhi kunjungan lansia ke posyandu lansia.

\section{KESIMPULAN DAN SARAN}

Hasil uji statistik untuk masing-masing bentuk dukungan keluarga, didapatkan bahwa dukungan emosional keluarga, mempunyai hubungan yang bermakna dengan kunjungan lansia ke posyandu lansia di Gunung Sempu Kelurahan Tamantito Kasihan Bantul Yogyakarta.

\section{DAFTAR PUSTAKA}

Darmadjo, B (2006). Geriatri. Jakareta : FKUI

Dharmadi, A. (2005). Akhir kehidupan dan berbagai problematrikanya.Mqajalah kedokteran Atma Jaya, Mesi (4) (2). Jakarta: FK Universitas Katolik Indonesia Atma Jaya

Nugroho, W. (2000). Keperawatan Gerotik Edisi 2. EGC. Jakrta.

Puskesmas Kasihan I (2008). Buku Kunjungan Lansia ke Posyandu Lansia. Tidak dipublikasikan.

Sunartono. (2008). Sosialisasi Penanganan Lansia bagi kader lansia dan Tokoh Masyarakat. Diakses oktober 2008 dari www.slemankab.go.id/index1.php?hal=de tail_berita.php\&id=1698

Puskesmas Kasihan I (2008). Buku Kunjungan Lansia ke Posyandu Lansia. Tidak dipublikasikan. 